\title{
Chemical weathering indices applied to soils developed on old lake sediments in a semi-arid region of Turkey
}

\section{Tülay Tunçay a, Orhan Dengiz b,* , Ilhami Bayramin c, Seref Kilic d, Oguz Baskan a}

a Soil Fertilizer and Water Resources Center Research Institute, Yenimahalle, Ankara, Turkey

b Ondokuz Mayis University, Faculty of Agriculture, Department of Soil Science and Plant Nutrition, Samsun, Turkey

c Ankara University, Faculty of Agriculture, Department of Soil Science and Plant Nutrition, Ankara, Turkey

d Ardahan University, Faculty of Engineerinf, Department of Environmental Engineering, Ardahan, Turkey

\section{Article Info}

Received : 18.03.2018

Accepted : 11.12 .2018

\begin{abstract}
Climate is a major influence on weathering processes affecting soil parent materials. Important contributors to soil formation in arid and semi-arid climatic zones are the diurnal cycles of solar heating and cooling that cause mechanical or physical disintegration of rock or parent materials, and wind-blown sands that score and abrade exposed rock surfaces. By using the Soil Taxonomy classification system, the initial aim of this study was to carry out a pedological evaluation for four soil profiles, classified as Xeric Haplocalcid and Xeric Haplocambid, formed on different parent materials (limestone, marl and old alluvial deposits) under the same conditions, including topography and vegetation, in a semiarid region. The second stage was the exploration of the similarities and differences in the classifications resulting from either the pedogenic processes, or from other factors, by determining the degree of soil weathering using geochemical data. To achieve this, soil samples were collected from the horizons to investigate their mineralogical, geochemical and physiochemical properties. The study also considered other features, such as the pedogenic evolution of soils, through the use of weathering indices, namely the Chemical Index of Alteration (CIA), Chemical Index of Weathering (CIW), Base/R203 Ratio, Weathering Index of Parker (WIP) and Plagioclase Index of Alteration (PIA). The results clearly showed that soil development at the Altınova State Farm at Konya in the Central Anatolia region of Turkey is due to slow pr ogressive weathering. For this case, the main indicators are secondary calcium carbonate illuviation and weak structural development with a weathering ratio of silicon to aluminium greater than two in all profiles.
\end{abstract}

Keywords: Alteration index, geochemical evolution, soil formation, dry region.

(C) 2019 Federation of Eurasian Soil Science Societies. All rights reserved

\section{Introduction}

To a pedologist or soil geographer, soil means a natural, three-dimensional body that has formed at the Earth's surface through the interactions of five soil-forming factors, namely climate, biota, relief, parent materials and time (Schaetzl and Anderson, 2005), and a field mapper is often able to explain and predict soil variation as a function of these five factors (Jenny, 1946; Johnson and Hole, 1994).

Soil formation is a dynamic rather than a static process, with soil developing where there is a dynamic interaction between the air, water, parent material and organisms. Wherever one or more of these major factors changes, the soil will be different. Significant differences in soil chemical, physical and morphological properties, particularly in a small area, are known to be related to the dynamic interaction between

\footnotetext{
${ }^{*}$ Corresponding author.

Ondokuz Mayıs University, Faculty ofAgriculture, Department of Soil Science and Plant Nutrition, 55139 Samsun, Turkey

Tel.: +903623121919

e-ISSN: 2147-4249

E-mail address: odengiz@omu.edu.tr DOI: 10.18393 /ejss.499122
} 
microclimate, topography and parent material (Lark, 1999; Dengiz et al., 2006), whereas the regional processes, macroclimate and vegetation, are important at the continental scale (Lark, 1999).

Weathering can be described as the physical and chemical alteration of rocks and minerals on or near the Earth's surface (Pope et al., 2002). In physical weathering, also known as mechanical weathering or disintegration, physical stresses combine to break rocks into smaller pieces. In contrast, water and oxygen are important to many chemical weathering reactions. Chemical weathering indices estimate the intensity of soil chemical weathering by comparing changes in major and trace metal concentrations as ratios of mobile to immobile elements in soil and rock or parent material. (Duzgoren-Aydin et al., 2002; Price and Velbel, 2003). These indices also provide a measure of the weathered state of the saprolite underlying the mobile soil column. This weathered condition is likely to play a critical role in governing how physical processes disrupt the saprolite, and is therefore an important parameter in determining resistance to alteration and erosion. Weathering indices are conventionally calculated using the molecular proportions of the oxides of major elements. Stoichiometrical changes during weathering are reflected in the index value. The molecular proportion of each oxide is easily calculated from the percentage of the oxide based on weight. Vogt (1927) proposed a geochemical method for assessing the maturity of residual sediments: the Vogt's Residual Index. The Chemical Index of Alteration (CIA) was proposed by Nesbitt and Young (1982) to quantitatively evaluate the weathering history recorded in sediments and sedimentary rocks. The CIA has been used to evaluate chemical weathering in specific drainage basins (McLennan, 1993; Yang et al., 2004). As the transformation of feldspar to clay minerals and the coincident mobility of the main cations are belong to a major chemical process, Parker (1970) proposed a more useful index known as the Weathering Index (WIP), which can evaluate minor changes in $\mathrm{Na}^{+}, \mathrm{K}^{+}, \mathrm{Ca}^{2+}$ and $\mathrm{Mg}^{2+}$. The Chemical Index of Weathering (CIW) was initially proposed by Harnois (1988). This index is similar to the CIA, except that it eliminates $\mathrm{K}_{2} \mathrm{O}$ from the equation. The Plagioclase Index of Alteration (PIA) was proposed by Fedo et al. (1995) as an alternative to the CIW. Because plagioclase is abundant in silicate and dissolves quickly, the PIA may be used when plagioclase weathering needs to be monitored.

The differences in soils are due to differences in variables such as parent material, topographical position, slope steepness, distribution of moisture, vegetation, and age of the associated landscape (Birkeland, 1999; Dengiz and Usul, 2018). Particularly, parent materials changes can affect many soil properties in local condition due to their minerological and textural variation.

By considering weathering indices, geochemical and mineralogical data, the present study was a pedological evaluation that aimed at identifying individual mineralogical and geochemical characteristics of aridisols with different parent materials but located in a similar topographical position, with similar climatic conditions, land use and vegetation. In addition, the second aim of the study was to determine how different parent materials located on old lake sediments affect the morphology, minerology and physicochemical properties of soils under similar conditions of topography and vegetation in a semi-arid region.

\section{Material and Methods}

\section{The study site description}

This study was carried out on an area of approximately 29608.6 ha in the Altınova State Farm, located between eastern longitudes 421239-4535249 m and northern latitudes 488389-4272469 m (Universal Transverse Mercator-UTM, WGS 84, $915 \mathrm{~m}$ ) (Figure 1) in the middle of central Anatolia, Turkey. The farm is located approximately $189 \mathrm{~km}$ from Ankara and about $126 \mathrm{~km}$ from Konya in the Great Konya Basin.

The pedological and geological properties of the soils and sediments, and the formation and diagenesis of carbonates under the lacustrine environment in the Great Konya Basin, have been investigated (de Ridder, 1965; Driessen and de Meester, 1969; Driessen, 1970; Vergouwen, 1981). A geological map of the study area is provided in Figure 2. The Great Konya Basin is predominantly occupied by Quaternary alluvial sediments (de Meester, 1971). According to their reports, during some periods of the Late Pleistocene epoch, most of the Great Konya Basin was covered by a shallow lake with a fairly constant water level of 12 to $20 \mathrm{~m}$, which left a number of sandy beach ridges and sand plains located roughly at the $1010 \mathrm{~m}$ contour. On top of the soft-lime lake bottom, a large variety of other sediments were deposited, resulting in various physiographic units, which divided the Great Konya Basin plain into uplands, colluvial slopes, piedmont plains, bajadas, terraces, alluvial plains and lacustrine plains. The terraces of the flat Neogene limestone formation are located along the fringes of the Great Konya Basin. The alluvial plains and fans comprise the sediments of some rivers debouching into the southern part of the basin. In addition, Özaytekin et al. (2012a) reported 
that the alluvial fans or inland deltas consist of sediments ranging from coarse sand to a heavy clay texture while the lacustrine plains are flat and contain carbonates. Deposited under water, the lacustrine plains cover vast areas in the centre of the Great Konya Basin. These ridges and shores were formed from the continual washing of the former Pleistocene lake (Roberts et al., 1979).

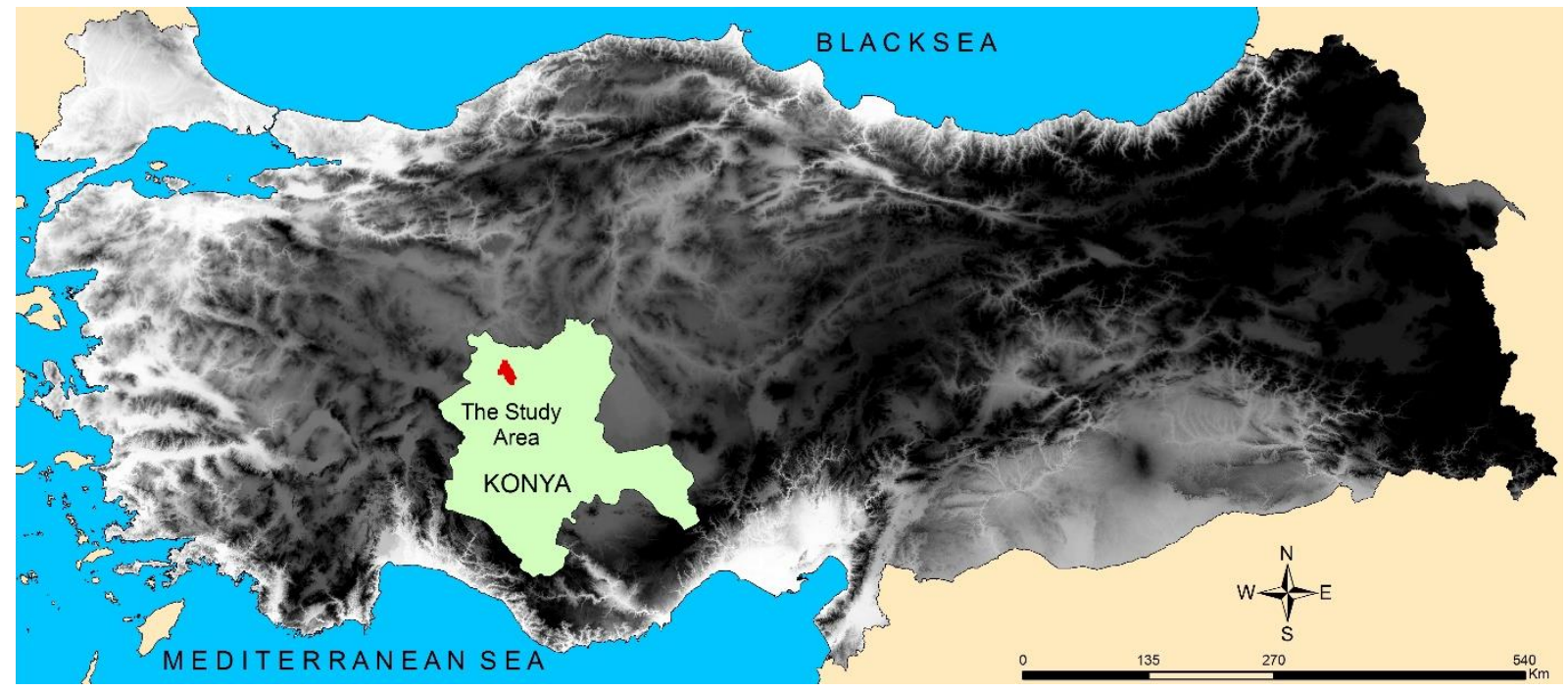

Figure 1. The study area

Over the long term (1999-2011), according to data from the State Farm's meteorological station, the mean annual precipitation is $302.3 \mathrm{~mm}$, the total evapotranspiration is $1296.1 \mathrm{~mm}$, and the mean annual temperature is $12.8^{\circ} \mathrm{C}$. Soil temperature and soil moisture regimes at the study site were classified according to the Soil Survey Staff as mesic and aridic (Soil Survey Staff, 1999), respectively. All farm land has been used as dry farming.

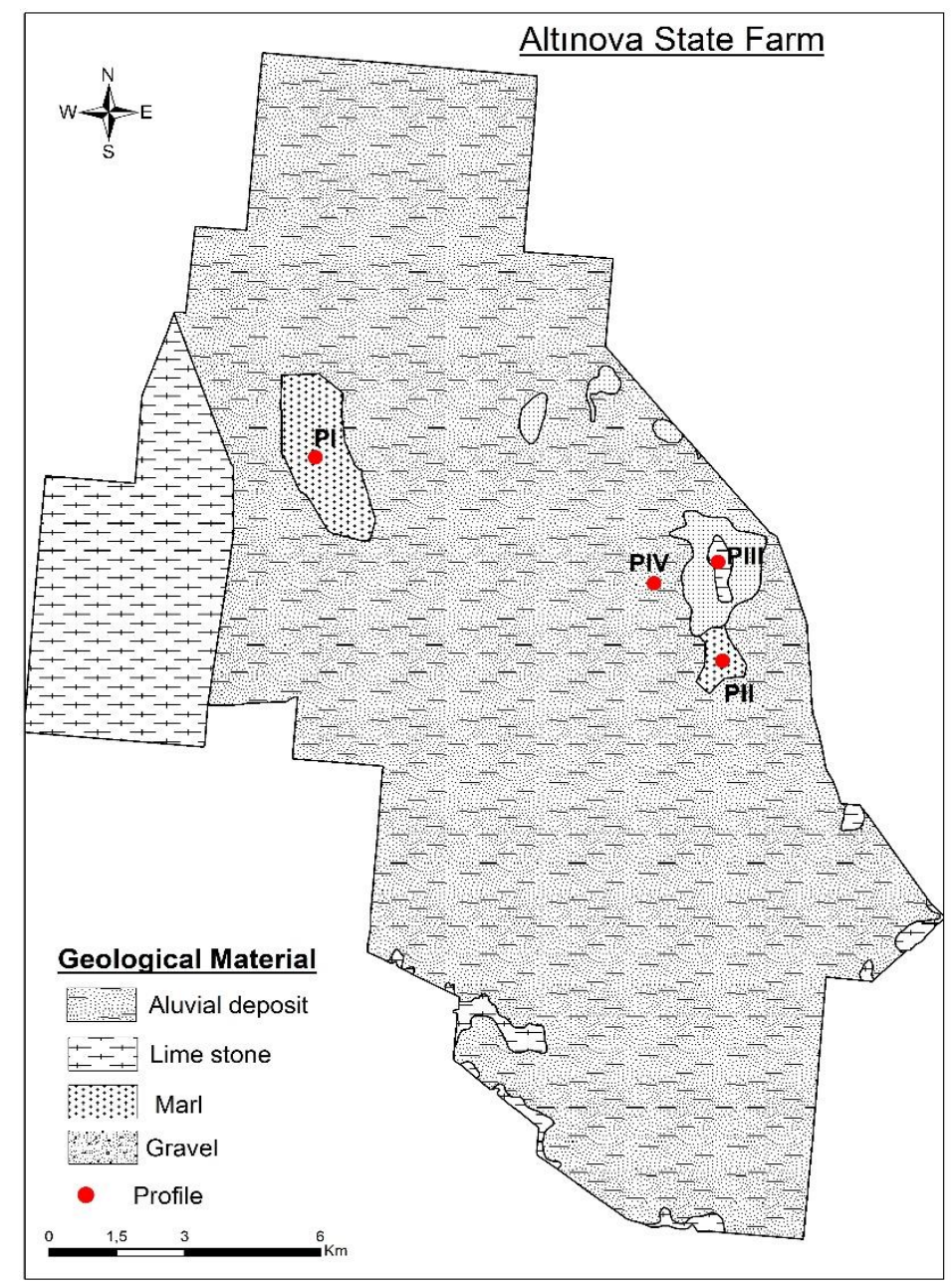

Figure 2. Geological map of the study area 


\section{Soil sampling}

Soil samples were collected from four representative profiles in the State Farm. In geological terms, profiles I and III were formed from hollow clay filler on Neogen old lake terraces and profiles II and IV were formed from subcreek alluvion material on Neogen old lake terraces. The morphological properties of these four profiles were described and sampled according to genetic horizons and then classified according to the Soil Survey Manual (1993) and Soil Survey Staff (1999). A total of nineteen disturbed soil samples in total were collected to investigate their physical, chemical and mineralogical properties in the laboratory. Soil samples were air-dried and passed through a $2 \mathrm{~mm}$ sieve to prepare them for laboratory analysis.

\section{Physical, chemical and mineralogical analysis}

After the soil samples taken from four soil profiles were air-dried and passed through a $2 \mathrm{~mm}$ sieve. Particle size distribution was determined with the hydrometer method (Bouyoucos, 1962). Organic matter was removed with 30 per cent $\mathrm{H}_{2} \mathrm{O}_{2}$, sulphate was removed by leaching salts with distilled water, and carbonates were removed with $1 \mathrm{M} \mathrm{NaOAc}$ at $\mathrm{pH}=5$ with dispersion, by agitating the sample in $10 \mathrm{ml}$ of 40 per cent sodium hexametaphosphate (Calgon) (Gee and Bauder, 1982). Bulk density was determined by using undisturbed samples (Black, 1965). Soil organic matter was measured by $\mathrm{Fe}_{2} \mathrm{SO}_{4}$ titration of an aciddichromate digestion (Walkley and Black, 1934). The methods of the Soil Survey Laboratory (2004) were used to determine the $\mathrm{pH}$ and EC (electrical conductivity) values of the saturated soil samples. $\mathrm{CaCO}_{3}$ content was measured with a Scheibler calsimeter (Soil Survey Manual, 1993), and exchangeable cations and cation exchange capacity (CEC) were measured with the $1 \mathrm{~N} \mathrm{NH}_{4} \mathrm{OAc}(\mathrm{pH}$ 7) method (Soil Survey Laboratory Manuals, 2004).

The clay fraction $(<2 \mu \mathrm{m})$ was obtained from the soil after the organic matter was removed with dilute, Naacetate-buffered $\mathrm{H}_{2} \mathrm{O}_{2}(\mathrm{pH}$ 5), followed by dispersal using calgon and sedimentation in water. Oriented specimens on glass slides were analyzed with X-ray diffraction, using $\mathrm{Cu} K \alpha$ radiation from $2^{\circ}$ to $15^{\circ} 2 \theta$, with steps of $0.02^{\circ} 2 \theta$ at two seconds per step. The following treatments were performed: Mg saturation, ethylene glycol solvation (EG) and $\mathrm{K}$ saturation, followed by heating for two hours at $550^{\circ} \mathrm{C}$. Minerals were identified and their relative abundance was determined by their diagnostic X-ray diffraction (XRD) spacing and evaluated by their XRD relative peak intensities in the XRD (Whittig and Allardice, 1986). Identification of selected major, trace and rare earth elements was done with an Inductively Coupled Plasma Mass Spectrometer (ICP-MS). Samples were taken into solution by alkaline fusion, using a mixture of $0.25 \mathrm{~g}$ soil or powdered sediment and $0.75 \mathrm{~g}$ of flux (lithium tetra- and metaborate) in $0.2 \mathrm{~N} \mathrm{HNO}_{3}$ solution diluted to 1:1000. An aliquot of the sample solution was analyzed for trace elements and the rare earth elements (REE) on a combination simultaneous/sequential ICP-MS. Detection limits were 0.1 to $1.0 \mathrm{ppm}$ for all major and trace elements and 0.1 to $0.5 \mathrm{ppm}$ for REE. The instrument was calibrated by using certified standard reference materials (OREAS24P and G1). To better evaluate the nature of soils and sediments and the effect of weathering and possible recycling of trace and rare earth elements in sediments under semi-arid conditions, a reference sediment was used for comparison; a North American Shale Composite (NASC) (Taylor and McLennan, 1985) was chosen for that purpose. All procedures were replicated three times for each soil sample, and the mean values were reported (Chao and Sanzolone, 1992).

\section{Calculation of weathering indices}

Numerous indices, including those of Nesbitt and Young (1982) and Harnois (1988), have been developed to characterize chemical weathering in soils. Those indices are similar in that they are based on the ratio of the base cations ( $\mathrm{Ca}, \mathrm{Mg}, \mathrm{K}$ and $\mathrm{Na}$ ) to $\mathrm{Al}$ and $\mathrm{Si}$. Weathering indices used to quantify chemical weathering intensity in the current study included the Chemical Index of Alternation (CIA) (Nesbitt and Young, 1982), Chemical Index of Weathering (CIW) (Harnois, 1988), Weathering Index of Parker (WIP), (Parker, 1970), Bases $/ \mathrm{R}_{2} \mathrm{O}_{3}$ Ratio (Birkeland, 1999), Plagioclase Index of Alteration (Fedo et al., 1995) and Product Index (P) (Reiche, 1950). CaO* represents the $\mathrm{CaO}$ contained only in the silicate fraction and is corrected for carbonate and apatite content. It is based on the assumption for $\mathrm{CaO}$ * that the molar $\mathrm{CaO} / \mathrm{Na}_{2} \mathrm{O}$ ratio of silicates is not higher than one. As the molar $\mathrm{CaO}$ content (corrected for apatite) was less than the molar $\mathrm{Na}_{2} \mathrm{O}$ content, the value was taken as $\mathrm{CaO}^{*}$. On the other occasions, the $\mathrm{CaO}$ content of silicates was supposed to be equivalent to the molar $\mathrm{Na}_{2} \mathrm{O}$ content (McLennan, 1993). 


\section{Results and Discussion}

\section{Morphological properties and classification}

A description of the study site and four representative soil profiles are provided in Table 1. All profiles were from flat land, with profiles I and II formed on marl parent material, profile III formed on limestone, and profile IV formed on an alluvial deposit (Figure 2).

Table 1. Selected site characteristics of pedons

\begin{tabular}{llllllll}
\hline \multirow{2}{*}{$\begin{array}{l}\text { Pedon } \\
\text { No }\end{array}$} & \multicolumn{2}{c}{ Coordinates } & Parent & $\begin{array}{l}\text { Elevation } \\
(\mathrm{m})\end{array}$ & $\begin{array}{l}\text { Slope } \\
\text { Position }\end{array}$ & $\begin{array}{l}\text { Slope } \\
(\%)\end{array}$ & $\begin{array}{l}\text { Land cover } \\
\text { Land Use }\end{array}$ \\
\cline { 2 - 6 } I & East & North & Material & 989 & Flat & $0-0.5$ & Dryfarming \\
II & 420723 & 4287966 & Marl & 988 & Flat & $0-1$ & Dryfarming \\
III & 420025 & 4291459 & Marl & 985 & Flat & $0-2$ & Dryfarming \\
IV & 419884 & 4292524 & Limestone & Flat & $0-1$ & Dryfarming \\
\hline
\end{tabular}

Soils in the study area display variations in terms of particle size distribution, color and surface horizon depth. Differences in the soils represent the effects of parent material because they developed under similar climate, topographical position and land use-vegetation conditions. Profiles I and II developed on the marl, while profile III developed on the limestone, as a result of decomposition and fragmentation of the calcareous parent material. Secondary carbonate nodules were formed following the calcification process, which provides evidence for carbonate leaching and accumulation in profiles I, III and IV, but not in profile II. A cambic B horizon was initially found in each profile according to weak soil structure development and light soil color. This result is consistent with previous research which found that a cambic horizon developed along with a calcic horizon in soils of arid and semi-arid regions (Buringh, 1979; Boul et al., 1980; Dinc et al., 1987). This effect and result was seen in profiles I, III and IV.

Soil color was closely related to the parent materials, namely marl and alluvial deposits, with a hue of $10 \mathrm{YR}$ in profiles I, II and IV, and 7.5 YR in profile III. For all profiles, the soil had a weak or moderately developed A horizon with a granular, angular, blocky structure; a weak or moderately developed B horizon with a granular, sub-angular or angular blocky structure; and a C horizon with a massive structure (Table 2). Soil Survey Staff (1999) classification system was used in this study. Profile I, formed on marl parent material on the old Neogen lake terraces was classified as Xeric Haplocambid. The main diagnostic horizon in profile I was the subsurface cambic horizon, resulting from structural development, observed especially at depths between 21 and $72 \mathrm{~cm}$. Common secondary carbonate nodules and micelles were observed at depths between 72 to $107 \mathrm{~cm}$. Profile II, on marl parent material on the old Neogen lake terraces, was classified as Xeric Haplocambid. The main diagnostic horizon in profile II was the subsurface cambic horizon, resulting from structural development, observed especially at depths between 41 and $75 \mathrm{~cm}$. However, there was no evidence of calcification and the calcic horizon evident in profile I. This finding indicates that profiles can form different soil genetic horizons from similar parent materials. Profile III, which formed on limestone and was classified as Xeric Haplocalcid, also showed a subsurface density diagnosic horizon, Ad, at depths between 14 and $26 \mathrm{~cm}$, due to intensive field traffic, and a subsurface cambic diagnostic horizon, Bw, at depths between 75 and $96 \mathrm{~cm}$. In addition, profile III showed the presence of secondary $\mathrm{CaCO}_{3}$ nodules and mycelia at depths between 96 to $127 \mathrm{~cm}$. Profile IV, which was formed on alluvial parent material, was classified as Xeric Haplocambid. The main diagnostic horizons in profile IV were subsurface the cambic horizons development observed at depths between 68 and $86 \mathrm{~cm}$, and common carbonate nodules and micelles at depths between 86 and $104 \mathrm{~cm}$ (Table 2). Therefore, the genetic order of profile IV is similar to profiles I and III, although their parent materials were not the same.

\section{Physical and chemical characteristics}

The major physical and chemical properties of the soils in each profile in the study area are presented in Table 3. Properties in the different profiles varied as a result of a dynamic interaction between climate and parent material (Dengiz, 2010; Kibar et al., 2012). Solum depth ranged from 20 to $127 \mathrm{~cm}$, depending upon the degree of weathering and the stage of the soil formation process. All profiles had a moderately alkaline soil ( $\mathrm{pH}$ value range from 7.81 to 8.25) and a slightly soluble salt content, with no substantial differences among them. The main reasons for particle size distribution differences between the soil profiles were the differences in chemical and minerological composition in their parent materials, including rocks. The dominant soil texture for profiles I, II and III was clay or clay loam, with the highest clay content in the Xeric 
Haplocalcid (profile III) developed on limestone parent material, and the highest sand content ranged from 60.16 to $66.39 \%$ in profile IV which was formed on alluvial parent material.

Table 2. Morphological properties and classification (Soil Taxonomy) of pedons

\begin{tabular}{|c|c|c|c|c|c|c|}
\hline Horizon & $\begin{array}{l}\text { Depth } \\
(\mathrm{cm})\end{array}$ & $\begin{array}{l}\text { Color } \\
\text { (dry) }\end{array}$ & $\begin{array}{l}\text { Color } \\
\text { (moisture) }\end{array}$ & Structure & Boundry & Special features \\
\hline \multicolumn{7}{|c|}{ Pedon I (Xeric Haplocambid) } \\
\hline Ap & $0-21$ & 10 YR 5 /2 & $10 \mathrm{YR} 4 / 2$ & $1 \mathrm{mgr}$ & as & \multirow{4}{*}{$\begin{array}{l}\text { - } \\
\text { structure development } \\
\text { structure development } \\
\text { common carbonate nodules } \\
\text { and micelles }\end{array}$} \\
\hline Bw1 & $21-45$ & 10 YR $5 / 3$ & 10 YR $4 / 3$ & $1 \mathrm{msbk}$ & gw & \\
\hline Bw2 & $45-72$ & 10 YR $5 / 6$ & $10 \mathrm{YR} 4 / 6$ & $1 \mathrm{msbk}$ & ga & \\
\hline $\mathrm{Ck}$ & $72-107$ & $10 \mathrm{YR} 8 / 3$ & 10 YR $7 / 3$ & mas & ga & \\
\hline $\mathrm{C} 2$ & $107-152$ & 10 YR $8 / 4$ & 10YR $7 / 4$ & mas & - & - \\
\hline \multicolumn{7}{|c|}{ Pedon II (Xeric Haplocambid) } \\
\hline Ap & $0-21$ & 10 YR $5 / 3$ & $10 \mathrm{YR} 4 / 3$ & $1 \mathrm{fgr}$ & cs & - \\
\hline A2 & $21-41$ & 10 YR $5 / 3$ & 10 YR $4 / 3$ & $1 \mathrm{fgr}$ & cs & - \\
\hline $\mathrm{Bw}$ & $41-75$ & 7.5 YR 6/6 & 7.5 YR 5/6 & $1 \mathrm{fgr}$ & cs & structure development \\
\hline $\mathrm{C} 1$ & $75-101$ & 7.5 YR 7/6 & 7.5 YR $6 / 6$ & mas & - & - \\
\hline $\mathrm{C} 2$ & $101-130$ & 7.5 YR $7 / 6$ & 7.5 YR $6 / 6$ & mas & - & - \\
\hline \multicolumn{7}{|c|}{ Pedon III (Xeric Haplocalcid) } \\
\hline Ap & $0-14$ & 7.5 YR $4 / 3$ & 7.5 YR $3 / 3$ & $2 \mathrm{fgr}$ & as & - \\
\hline Ad & $14-26$ & 7.5 YR $4 / 3$ & 7.5 YR $3 / 3$ & mas & gw & - \\
\hline A3 & $26-75$ & 7.5 YR $5 / 3$ & 7.5 YR $4 / 3$ & $1 \mathrm{cabk}$ & gw & - \\
\hline Bw & $75-96$ & 7.5 YR 5/6 & 7.5 YR $4 / 6$ & $1 \mathrm{mabk}$ & gw & structure development \\
\hline $\mathrm{Bk}$ & $96-127$ & 7.5 YR 6/6 & 7.5 YR 5/6 & $2 \mathrm{mabk}$ & gw & carbonate micelles \\
\hline $\mathrm{C}$ & $127-165$ & 7.5 YR $6 / 6$ & 7.5 YR 5/6 & mas & - & - \\
\hline \multicolumn{7}{|c|}{ Pedon IV (Xeric Haplocambid) } \\
\hline Ap & $0-24$ & 10 YR $4 / 2$ & 10 YR 4/1 & $2 \mathrm{mgr} / 1 \mathrm{mabk}$ & gs & - \\
\hline $\mathrm{A} 2$ & $24-67$ & 10 YR $4 / 3$ & 10 YR $4 / 2$ & $3 \mathrm{mabk}$ & $\mathrm{cW}$ & - \\
\hline $\mathrm{Bw}$ & $67-86$ & 10 YR $5 / 4$ & $10 \mathrm{YR} 4 / 4$ & $2 \mathrm{mabk}$ & $\mathrm{cW}$ & \multirow{2}{*}{$\begin{array}{l}\text { structure development } \\
\text { common carbonate nodules } \\
\text { and micelles }\end{array}$} \\
\hline $\mathrm{Bk}$ & $86-104$ & 10 YR 4/6 & 10 YR 4/4 & $1 \mathrm{msbk}$ & ga & \\
\hline $\mathrm{C}$ & $104-150$ & 10 YR $5 / 6$ & 10 YR 4/6 & mas & - & - \\
\hline
\end{tabular}

Abreviations: Boundary: $\mathrm{a}=$ abrupt; $\mathrm{c}=$ clear; $\mathrm{g}=$ gradual; $\mathrm{d}=$ diffuse; $\mathrm{s}=$ smooth; $\mathrm{w}=$ wavy; $\mathrm{i}=$ irregular. Structure: $1=$ weak; 2 = moderate; 3 = strong; $\mathrm{sg}=$ single grain; mas = massive; $\mathrm{vf}=$ very fine; $\mathrm{f}=$ fine; $\mathrm{m}=$ medium; $\mathrm{c}=$ coarse; $\mathrm{gr}=$ granular; $\mathrm{pr}=$ prismatic; abk = angular blocky; sbk = subangular blocky

Soil Cation Exchange Capacity (CEC) varied from 14.3 to $56.8 \mathrm{cmolc} \mathrm{kg}^{-1}$, with the highest CEC in the Xeric Haplocambid (profile II), in which smectite was the predominant clay type, indicating the presence of stratified aluminosilicates with high load intensity. The lowest CEC value was found in soil classified as Xeric Haplocambid (profile I). Ca and Mg were the dominant exchangeable cations in all profiles, with a base saturation value of $100 \%$. As there is little deposition and accumulation of organic litter in arid and semiarid zones, the organic matter content of the soils was low. When these soils are cultivated, the limited organic matter content is quickly decomposed (Da Costa et al., 2015). For all profiles in the study area, the organic matter content was highest (1.0 to $1.6 \%$ ) in the surface horizon and lowest in the subsurface horizons (0.4 to $1.4 \%$ ), with an abrupt decrease in the subsurface horizon. The low levels of organic matter in the subsoil can be attributed to the rapid decomposition and mineralization of organic matter.

Soil bulk density values ranged from 1.33 to $1.70 \mathrm{~g} \mathrm{~cm}^{-3}$, with values generally higher in the surface horizons, especially Ap horizons, than in subsurface horizons, as a result of compaction by the relatively intensive field traffic associated with agricultural activities. Profiles I and II were formed on the same parent material (marl) but the $\mathrm{CaCO}_{3}$ content of these profiles was different; profile I had the highest $\mathrm{CaCO}_{3}$ content of $57.7 \%$, and calcium carbonate accumulation in the calcic horizon. Profile IV developed on alluvial parent material and had the lowest $\mathrm{CaCO}_{3}$ content of all profiles. 


\begin{tabular}{|c|c|c|c|c|c|c|c|c|c|c|c|c|c|c|}
\hline \multirow[t]{2}{*}{ Horizon } & \multirow[t]{2}{*}{$\begin{array}{l}\text { Depth } \\
(\mathrm{cm})\end{array}$} & \multirow[t]{2}{*}{$\begin{array}{l}\mathrm{pH}(\mathrm{H} 20) \\
(1 / 2.5)\end{array}$} & \multirow[t]{2}{*}{$\begin{array}{l}\text { EC } \\
\left(\mathrm{dS} \cdot \mathrm{m}^{-1}\right)\end{array}$} & \multirow[t]{2}{*}{$\begin{array}{l}\mathrm{CaCO}_{3} \\
(\%)\end{array}$} & \multirow[t]{2}{*}{$\begin{array}{l}\mathrm{OM} \\
(\%)\end{array}$} & \multicolumn{3}{|c|}{$\begin{array}{c}\text { Exchangeable Cations } \\
\left(\mathrm{cmolc} \cdot \mathrm{kg}^{-1}\right)\end{array}$} & \multirow{2}{*}{$\begin{array}{l}\text { CEC } \\
\left(\mathrm{c} \mathrm{mol} \cdot \mathrm{kg}^{-1}\right)\end{array}$} & \multirow[t]{2}{*}{$\begin{array}{l}\mathrm{BD} \\
\left(\mathrm{gr}, \mathrm{cm}^{-3}\right)\end{array}$} & \multicolumn{4}{|c|}{ PSD ( $\%)$} \\
\hline & & & & & & $\mathrm{Na}$ & $\mathrm{K}$ & $\mathrm{Ca}+\mathrm{Mg}$ & & & $\mathrm{C}$ & $\mathrm{Si}$ & $\mathrm{S}$ & Class \\
\hline \multicolumn{15}{|c|}{ Pedon I (Xeric Haplocambid) } \\
\hline Ap & $0-21$ & 8.12 & 0.43 & 12.40 & 1.20 & 0.60 & 1.70 & 40.30 & 42.80 & 1.42 & 30.80 & 29.10 & 40.20 & CL \\
\hline Bw1 & $21-45$ & 8.14 & 0.41 & 31.50 & 1.10 & 0.60 & 0.50 & 38.20 & 39.60 & 1.35 & 35.10 & 24.90 & 40.00 & $\mathrm{CL}$ \\
\hline Bw2 & $45-72$ & 7.81 & 0.45 & 41.50 & 1.10 & 0.70 & 0.70 & 31.20 & 32.60 & 1.34 & 34.90 & 24.80 & 40.40 & CL \\
\hline $\mathrm{Ck}$ & $72-107$ & 7.93 & 0.51 & 57.70 & 1.00 & 0.70 & 0.50 & 23.30 & 24.90 & 1.41 & 11.70 & 49.40 & 38.90 & L \\
\hline C2 & $107-152$ & 8.01 & 1.23 & 41.40 & 0.70 & 1.40 & 0.40 & 13.70 & 14.30 & 1.47 & 11.80 & 18.50 & 69.80 & SL \\
\hline \multicolumn{15}{|c|}{ Pedon II (Xeric Haplocambid) } \\
\hline Ap & $0-21$ & 8.25 & 0.43 & 4.20 & 1.00 & 1.20 & 1.70 & 53.20 & 56.40 & 1.33 & 35.45 & 29.06 & 35.49 & $\mathrm{CL}$ \\
\hline A2 & $21-41$ & 8.06 & 0.37 & 10.70 & 0.80 & 1.00 & 1.20 & 54.80 & 56.80 & 1.44 & 46.49 & 25.01 & 28.50 & $\mathrm{C}$ \\
\hline Bw & $41-75$ & 8.02 & 0.33 & 19.90 & 0.40 & 0.80 & 1.00 & 52.20 & 54.20 & 1.38 & 52.81 & 22.80 & 24.39 & $\mathrm{C}$ \\
\hline \multicolumn{15}{|c|}{ Pedon III (Xeric Haplocalcid) } \\
\hline Ap & $0-14$ & 8.22 & 0.47 & 12.10 & 1.60 & 0.70 & 2.70 & 48.20 & 51.60 & 1.41 & 31.10 & 33.23 & 35.67 & $\mathrm{CL}$ \\
\hline Ad & $14-26$ & 7.91 & 0.58 & 10.40 & 1.40 & 0.70 & 2.10 & 48.00 & 51.10 & 1.46 & 39.88 & 29.18 & 30.94 & $\mathrm{CL}$ \\
\hline $\mathrm{A} 3$ & $26-75$ & 7.98 & 0.47 & 15.90 & 0.90 & 0.80 & 1.30 & 50.30 & 53.50 & 1.41 & 47.52 & 21.60 & 30.89 & C \\
\hline Bw & $75-96$ & 7.85 & 0.32 & 22.90 & 0.50 & 0.90 & 1.20 & 47.00 & 49.20 & 1.39 & 59.39 & 20.71 & 19.89 & $\mathrm{C}$ \\
\hline $\mathrm{Bk}$ & $96-127$ & 7.96 & 0.34 & 27.80 & 0.40 & 1.20 & 1.20 & 46.00 & 50.20 & 1.38 & 61.66 & 20.75 & 17.58 & $\mathrm{C}$ \\
\hline C & $127-165$ & 8.01 & 0.57 & 16.30 & 0.40 & 1.60 & 1.20 & 52.10 & 55.30 & 1.37 & 40.34 & 23.03 & 36.63 & $\mathrm{C}$ \\
\hline \multicolumn{15}{|c|}{ Pedon IV (Xeric Haplocambid) } \\
\hline Ap & $0-24$ & 7.92 & 0.44 & 1.20 & 1.40 & 0.60 & 1.60 & 33.10 & 35.50 & 1.48 & 21.59 & 12.01 & 66.39 & SCL \\
\hline $\mathrm{A} 2$ & $24-67$ & 8.00 & 0.36 & 1.30 & 1.20 & 0.60 & 1.00 & 31.20 & 33.10 & 1.64 & 26.04 & 9.03 & 64.94 & SCL \\
\hline Bw & $67-86$ & 7.85 & 0.34 & 4.20 & 0.90 & 0.60 & 0.80 & 27.30 & 29.70 & 1.58 & 22.66 & 11.00 & 66.34 & SCL \\
\hline $\mathrm{Bk}$ & $86-104$ & 7.94 & 0.34 & 9.20 & 1.30 & 0.60 & 0.70 & 26.30 & 27.60 & 1.64 & 21.60 & 12.02 & 66.38 & SCL \\
\hline $\mathrm{C}$ & $104-150$ & 8.01 & 0.31 & 9.60 & 1.10 & 0.60 & 0.70 & 25.20 & 27.60 & 1.70 & 21.62 & 18.23 & 60.16 & SCL \\
\hline
\end{tabular}

Abreviations: EC: Electrical Conductivity, OM: Organic Matter, CEC: Cation Exchange Capacity, BD: Bulk Density,

PSD: Particle Size Distribution, C: Clay, Si: Silt, S: Sand L: Loamy, CL: Clay Loamy, SCL: Sandy Clay Loamy

\section{Weathering indices and clay mineralogy}

Chemical weathering indices are commonly used to quantitatively evaluate changes caused by chemical weathering in different materials (Birkeland, 1999; Darmody et al., 2005; Vogt, 1927; Ruxton, 1968; Harnois, 1988). The indices are based on the principle that the ratio between concentrations of mobile (e.g. $\mathrm{SiO}_{2}, \mathrm{CaO}_{\text {, }}$ $\mathrm{MgO}$ and $\mathrm{Na}_{2} \mathrm{O}$ ) and immobile (e.g. $\mathrm{Al}_{2} \mathrm{O}_{3}, \mathrm{Fe}_{2} \mathrm{O}_{3}$ and $\mathrm{TiO}_{2}$ ) elements will decrease over time as leaching progresses. However, the weathering of heterogeneous metamorphic rocks confounds the understanding of the relationship between the weathering index and depth (Dengiz et al., 2013).

Weathering indices calculated from elemental oxide concentrations in molecular proportions are also used to evaluate the vertical changes in a weathering profile. In addition, generally, weathering indices change systematically for soil profiles formed from homogeneous parent rocks with depth. In the current study, six previously defined chemical weathering indices were used to evaluate four profiles under similar climatic and topographic conditions. Major and minor element concentrations in the studied profiles, some weathering rates obtained from the geochemical features of the soils, and some genetic rates, are provided in Tables 4 and 5.

According to total element analyses showed that the $\mathrm{SiO}_{2}$ content in all profiles decreased with depth (range of 52.32 to $25.40 \%$ ) and that $\mathrm{Al}_{2} \mathrm{O}_{3}$ values varied from 4.99 to $13.11 \% . \mathrm{SiO}_{2}$ strongly resists weathering because it is mainly contained in quartz minerals. In contrast, $\mathrm{Al}_{2} \mathrm{O}_{3}$ is mainly is less resistant to weathering because it is contained in the clay minerals; a high content of $\mathrm{Al}_{2} \mathrm{O}_{3}$ indicates a high content of clay minerals (Shan et al., 2010). The highest amount of $\mathrm{Fe}_{2} \mathrm{O}_{3}$ (5.72\%) was in profile II. These results are supported by XRD analysis. In regions where the parent materials are mostly marl and limestone, elevated concentrations of $\mathrm{CaO}$ and $\mathrm{MgO}$ are seen in the soils. Generally, the $\mathrm{CaO}$ content in these soils range from 1 to $11 \%$, but in some cases the $\mathrm{CaO}$ content increases to between 11 and 24\%, or even higher (Alumaa et al., 2001).

The CIA index was proposed by Nesbitt and Young (1982) in the reconstruction of the paleoclimate from Early Proterozoic sediments of the Huronian Supergroup, north of Huron Lake. The CIA is based on the progressive removal of soluble cations (e.g. $\mathrm{Ca}$, $\mathrm{Na}$, and $\mathrm{K}$ ) from minerals during chemical weathering, and it reflects the proportion of primary and secondary minerals in the bulk sample (Nesbitt and Young, 1982). Generally, rocks from the upper crust and unweathered igneous rocks have CIA values of $\sim 50$, whereas the soils and sediments derived from intensely weathered rocks, and containing residual clay minerals such as kaolinite and/or gibbsite, have CIA values approaching 100 (Fedo et al., 1995; Ao et al., 2010; Özaytekin et al., 2012b). The value ranges from 70 to 75 for shale rock.

In the profiles examined in the current study, the CIA values varied from 6.60 to 66.88 . The highest and lowest CIA values were in the A and C horizons of the Xeric Haplocambid (profil IV and profile I), 
respectively. The CIA values decreased with depth in all profiles. In other words, the parent materials of all profiles had the lowest CIA values of all layers. Nesbitt and Young (1982) classified the CIA values as very slightly weathered (50 to 60 ), slightly weathered (60 to 70 ), moderately weathered (70 to 80 ), highly weathered ( 80 to 90$)$, and extremely weathered (90 to100).

Table 4. Some major and minor element concentrations of the studied pedons

\begin{tabular}{|c|c|c|c|c|c|c|c|c|c|c|c|c|c|c|c|c|c|}
\hline \multirow{2}{*}{ Pedon } & \multicolumn{8}{|c|}{ Major Elements (\%) } & \multicolumn{9}{|c|}{ Minor Elements (ppm) } \\
\hline & $\mathrm{SiO}_{2}$ & $\mathrm{Al}_{2} \mathrm{O}_{3}$ & $\mathrm{Fe}_{2} \mathrm{O}_{3}$ & $\mathrm{MgO}$ & $\mathrm{CaO}$ & $\mathrm{Na}_{2} \mathrm{O}$ & $\mathrm{K}_{2} \mathrm{O}$ & $\mathrm{TiO}_{2}$ & $\mathrm{P}_{2} \mathrm{O}_{5}$ & $\mathrm{Ba}$ & $\mathrm{Zn}$ & $\mathrm{Cu}$ & $\mathrm{Pb}$ & $\mathrm{Ni}$ & $\mathrm{Nb}$ & $\mathrm{Rb}$ & $\mathrm{Sr}$ \\
\hline \multicolumn{18}{|c|}{ Pedon I (Xeric Haplocambid) } \\
\hline Ap & 46.52 & 11.80 & 5.30 & 2.54 & 7.72 & 0.07 & 2.07 & 0.61 & 0.13 & 973.7 & 64.7 & 21.9 & 25.5 & 63.1 & 19.1 & 85.3 & 737.1 \\
\hline Bw1 & 41.84 & 10.19 & 4.60 & 2.50 & 17.69 & 0.07 & 1.70 & 0.55 & 0.14 & 843.4 & 51.2 & 18.2 & 24.4 & 55.2 & 12.7 & 69.1 & 828.4 \\
\hline Bw2 & 38.15 & 9.06 & 3.99 & 2.22 & 25.13 & 0.08 & 1.47 & 0.49 & 0.12 & 714.7 & 43.4 & 11.8 & 19.9 & 43.1 & 13.3 & 58.8 & 933.7 \\
\hline $\mathrm{Ck}$ & 25.40 & 4.99 & 2.64 & 2.09 & 38.22 & 0.08 & 0.81 & 0.33 & 0.06 & 477.8 & 26.5 & 6.7 & 14.1 & 29.3 & 9.2 & 35.1 & 1093.0 \\
\hline $\mathrm{C} 2$ & 35.08 & 7.41 & 3.62 & 2.63 & 24.94 & 0.07 & 1.22 & 0.43 & 0.09 & 1126.0 & 39.1 & 11.7 & 18.1 & 43.4 & 10.8 & 52.3 & 1408.0 \\
\hline \multicolumn{18}{|c|}{ Pedon II (Xeric Haplocambid) } \\
\hline A2 & 45.82 & 12.56 & 5.72 & 2.25 & 8.06 & 0.07 & 1.99 & 0.64 & 0.09 & 952.8 & 68.9 & 23.6 & 26.6 & 64.4 & 23.8 & 91.6 & 640.1 \\
\hline Bw & 41.71 & 11.54 & 5.33 & 2.06 & 13.76 & 0.07 & 1.76 & 0.60 & 0.11 & 909.2 & 61.7 & 23.5 & 25.2 & 62.6 & 16.7 & 85.3 & 706.9 \\
\hline C1 & 34.47 & 7.26 & 3.84 & 1.96 & 16.74 & 0.07 & 1.33 & 0.42 & 0.08 & 789.5 & 49.7 & 21.2 & 18.3 & 46.2 & 14.4 & 62.8 & 828.0 \\
\hline $\mathrm{C} 2$ & 38.03 & 8.51 & 4.59 & 1.86 & 18.05 & 0.07 & 1.58 & 0.49 & 0.09 & 644.9 & 51.4 & 18.1 & 19.2 & 48.1 & 18.8 & 70.7 & 599.5 \\
\hline \multicolumn{18}{|c|}{ Pedon III (Xeric Haplocalcid) } \\
\hline Ap & 50.55 & 12.61 & 5.28 & 3.02 & 9.03 & 0.07 & 2.09 & 0.62 & 0.17 & 968.1 & 65.9 & 23.3 & 29.4 & 66.8 & 23.3 & 87.2 & 824.7 \\
\hline Ad & 48.58 & 12.41 & 5.24 & 2.92 & 7.55 & 0.06 & 2.03 & 0.61 & 0.13 & 885.8 & 68.1 & 23.2 & 28.3 & 69.1 & 19.5 & 89.2 & 696.9 \\
\hline $\mathrm{A} 3$ & 44.99 & 11.68 & 5.43 & 2.88 & 11.43 & 0.07 & 1.91 & 0.62 & 0.12 & 809.1 & 64.1 & 23.9 & 26.2 & 68.4 & 21.3 & 85.7 & 646.9 \\
\hline $\mathrm{Bk}$ & 38.38 & 9.84 & 4.77 & 2.73 & 17.26 & 0.07 & 1.53 & 0.53 & 0.10 & 683.8 & 56.9 & 21.9 & 23.9 & 56.2 & 20.8 & 73.5 & 745.8 \\
\hline C & 41.03 & 10.63 & 5.05 & 2.89 & 13.94 & 0.06 & 1.64 & 0.57 & 0.07 & 966.6 & 65.7 & 24.3 & 28.3 & 71.1 & 18.5 & 83.1 & 804.5 \\
\hline \multicolumn{18}{|c|}{ Pedon IV (Xeric Haplocambid) } \\
\hline Ap & 52.32 & 12.70 & 5.13 & 1.80 & 1.75 & 0.21 & 2.56 & 0.60 & 0.12 & 1885.0 & 56.8 & 21.0 & 28.9 & 51.0 & 18.8 & 89.8 & 1381.0 \\
\hline $\mathrm{A} 2$ & 51.26 & 13.11 & 5.58 & 2.66 & 5.13 & 0.07 & 2.27 & 0.66 & 0.17 & 922.8 & 70.6 & 24.0 & 28.8 & 68.7 & 21.9 & 95.5 & 598.9 \\
\hline Bw & 47.83 & 12.91 & 5.62 & 2.00 & 5.53 & 0.07 & 2.46 & 0.59 & 0.09 & 1827.0 & 50.5 & 19.1 & 27.6 & 50.9 & 22.9 & 82.0 & 1330.0 \\
\hline $\mathrm{Bk}$ & 49.62 & 12.22 & 4.83 & 2.00 & 8.89 & 0.07 & 240 & 0.52 & 0.15 & 2050.0 & 47.7 & 14.1 & 29.2 & 40.5 & 19.5 & 77.7 & 1740.0 \\
\hline $\mathrm{C}$ & 49.51 & 12.87 & 5.12 & 2.33 & 8.60 & 0.10 & 2.38 & 0.57 & 0.12 & 1729.0 & 48.2 & 16.6 & 28.5 & 47.0 & 18.1 & 81.2 & 1471.0 \\
\hline
\end{tabular}

When the CIA classification was applied in the current study, the surface horizons of all profiles, except for profile IV, were classified as very slightly weathered. On the other hand, all subsurface horizons were in the same class (very slightly weathered). In addition, there was no obvious trend towards progressively higher alteration values for soils developed on different parent materials. Harnois (1988) proposed the Chemical Index of Weathering (CIW) which modified CIA by excluding $\mathrm{K}_{2} \mathrm{O}$ from assessments. Because the CIW does not account for the aluminium associated with K-feldspar, it may generate very high values for K-feldsparrich rocks, whether they are chemically weathered or not (Fedo et al.,1995).

Table 5. Weathering rate indices and some genetic ratios using rare earth elements (REE) of studied soils

\begin{tabular}{|c|c|c|c|c|c|c|c|c|c|c|c|c|}
\hline Horizon & Depth & CIA & CIW & WIP & PIA & $\mathrm{P}$ & $\mathrm{Baz} / \mathrm{R}_{2} \mathrm{O}_{3}$ & $\mathrm{~V}$ & $\mathrm{Th} / \mathrm{U}$ & $\mathrm{Ba} / \mathrm{Nb}$ & $\mathrm{Zr} / \mathrm{Rb}$ & $(\mathrm{Rb}+\mathrm{Zr}) / \mathrm{Sr}$ \\
\hline \multicolumn{13}{|c|}{ Pedon I (Xeric Haplocambid) } \\
\hline Ap & $0-21$ & 41.81 & 45.43 & 45.02 & 33.83 & 83.03 & 1.41 & 0.68 & 1.56 & 50.98 & 3.00 & 0.46 \\
\hline Bw1 & $21-45$ & 22.96 & 23.96 & 67.24 & 18.79 & 83.54 & 2.89 & 0.31 & 1.41 & 66.41 & 3.43 & 0.37 \\
\hline Bw2 & $45-72$ & 16.02 & 16.48 & 83.47 & 13.19 & 83.94 & 4.28 & 0.20 & 0.92 & 53.74 & 3.09 & 0.26 \\
\hline $\mathrm{Ck}$ & $72-107$ & 6.60 & 6.68 & 110.95 & 5.43 & 85.68 & 10.52 & 0.07 & 0.85 & 51.93 & 4.01 & 0.16 \\
\hline $\mathrm{C} 2$ & $107-152$ & 13.66 & 14.00 & 81.98 & 11.22 & 85.12 & 5.14 & 0.16 & 0.99 & 104.26 & 2.96 & 0.15 \\
\hline \multicolumn{13}{|c|}{ Pedon II (Xeric Haplocambid) } \\
\hline Ap & $0-21$ & 57.06 & 63.21 & 36.51 & 47.32 & 82.73 & 0.93 & 1.08 & 1.96 & 41.58 & 2.99 & 0.56 \\
\hline A2 & $21-41$ & 42.55 & 45.92 & 44.42 & 35.21 & 81.87 & 1.31 & 0.71 & 2.09 & 40.03 & 3.21 & 0.60 \\
\hline Bw & $41-75$ & 29.88 & 31.44 & 56.47 & 24.92 & 81.67 & 2.03 & 0.44 & 2.23 & 54.44 & 3.26 & 0.51 \\
\hline C1 & $75-101$ & 18.41 & 19.18 & 60.10 & 14.79 & 84.94 & 3.56 & 0.24 & 1.36 & 54.82 & 3.43 & 0.33 \\
\hline $\mathrm{C} 2$ & $101-130$ & 19.69 & 20.51 & 65.36 & 15.71 & 84.08 & 3.22 & 0.27 & 1.75 & 34.30 & 3.18 & 0.49 \\
\hline \multicolumn{13}{|c|}{ Pedon III (Xeric Haplocalcid) } \\
\hline Ap & $0-14$ & 40.11 & 43.23 & 49.86 & 32.88 & 83.49 & 1.56 & 0.61 & 1.99 & 41.55 & 2.93 & 0.42 \\
\hline Ad & $14-26$ & 43.58 & 47.24 & 45.26 & 35.83 & 83.15 & 1.40 & 0.68 & 2.42 & 45.43 & 2.98 & 0.51 \\
\hline A3 & $26-75$ & 33.68 & 35.82 & 54.04 & 27.70 & 82.57 & 1.88 & 0.48 & 2.08 & 37.99 & 2.82 & 0.51 \\
\hline Bw & $75-96$ & 22.46 & 23.35 & 66.25 & 18.66 & 82.58 & 2.95 & 0.29 & 1.91 & 45.72 & 2.84 & 0.36 \\
\hline $\mathrm{Bk}$ & $96-127$ & 22.85 & 23.77 & 65.30 & 18.98 & 82.61 & 2.92 & 0.29 & 2.18 & 32.88 & 2.69 & 0.36 \\
\hline C & $127-165$ & 28.04 & 29.43 & 58.19 & 23.33 & 82.51 & 2.34 & 0.37 & 1.89 & 52.25 & 2.93 & 0.41 \\
\hline \multicolumn{13}{|c|}{ Pedon IV (Xeric Haplocambid) } \\
\hline Ap & $0-24$ & 66.88 & 78.37 & 33.05 & 52.21 & 84.00 & 0.64 & 1.91 & 1.89 & 100.27 & 3.10 & 0.27 \\
\hline A2 & $24-67$ & 52.38 & 58.09 & 40.38 & 42.54 & 83.09 & 1.05 & 0.95 & 2.16 & 42.14 & 3.10 & 0.65 \\
\hline Bw & $67-86$ & 50.07 & 55.87 & 41.31 & 39.70 & 82.32 & 1.02 & 1.01 & 1.80 & 79.78 & 3.96 & 0.31 \\
\hline $\mathrm{Bk}$ & $86-104$ & 39.23 & 42.82 & 49.38 & 30.85 & 83.93 & 1.48 & 0.69 & 1.60 & 105.13 & 3.56 & 0.20 \\
\hline $\mathrm{C}$ & $104-150$ & 41.14 & 44.85 & 49.61 & 32.85 & 83.14 & 1.42 & 0.70 & 2.18 & 95.52 & 3.16 & 0.23 \\
\hline
\end{tabular}


In the present study, the CIW values ranged between 6.68 and 78.37 and tended to decrease with depth in all profiles. The value of CIW increased with weathering. If the classification for CIA is performed for CIW as well, it is evident that all the profiles developed on different parent material are in similar classes in terms of CIW values. This result indicates that the CIW and CIA indices display similar behaviour for the different parent material.

The base $/ \mathrm{R}_{2} \mathrm{O}_{3}$ values of all profiles ranged from 0.64 to 10.52. Parker's Weathering Index (WIP) is used to evaluate the intensity of the weathering of silicate rocks, based upon the proportion of alkali and alkaline earth elements in the products of weathering. The WIP also takes into account some individual mobilities, namely sodium, potassium, magnesium and calcium, on the basis of their bond strengths with oxygen (Parker, 1970). According to the definition of WIP, smaller WIP values indicate stronger chemical weathering, which is opposite to the manner in which CIA values are generated. This index has been suggested to be most appropriate for application to weathering profiles on heterogeneous parent rocks and is most likely not applicable to highly weathered mantles, because the assessment only includes highly mobile alkali and alkaline elements (Hamdan and Burnham, 1996; Duzgoren-Aydin et al., 2002; Price and Vebel, 2003). in In the present study, the WIP values of the soils formed on marl, limestone and alluvialdeposit parent rocks were between 36.51 and 110.95, 45.26 and 66.25, 33.05 and 49.61, respectively, and decreased with increasing weathering. The lowest WIP values were 33.05 in profile IV and 36.51 in profile II. These profiles were determined to be Xeric Haplocambid, whereas the C horizon of profile I, which developed on marl parent material, had the highest WIP value (110.95) and was deemed to be Xeric Haplocalcid.

There are two explanations for this phenomenon. Firstly, it means that the weathering process is more intense in Xeric Haplocambid profiles than in Xeric Haplocalcid profiles. Secondly, with time, the soil derived from the parent material diverges progressively from that of the parent material under the influence of the pedogenic process. In terms of parent material, the profile that developed on alluvial parent material showed the highest weathering, with the P index varying between 81.67 and 84.94 and tending to fluctuate slightly with depth in all profiles.

Fedo et al. (1995), proposed the Plagioclase Index of Alteration (PIA) as an alternative to the CIW. Because plagioclase is abundant in silicate and dissolves relatively rapidly, the PIA may be used when plagioclase weathering needs to be monitored (Fedo et al., 1995). In the present study, the PIA values tended to decrease with the depth in all profiles, with the Vogt's index value varying between 0.07 and 1.91 . CIW values also decreased with depth.

Another way to study the degree of chemical weathering of the soil profiles investigated was to calculate the relative change in REE (Rare Earth Element) concentration. The abundance of trace elements and REEs in sediments has been employed to provide clues as to both sources and changes in sediments from weathering and sedimentary processes, as in Taylor and McLennan (1985). Some ratios of geochemical elements are used to quantify the degree of weathering of studied profiles. The trace elements and REEs of the studied soils are normalized to chondrite (Wood et al., 1979). Normalized REE patterns can indicate the degree of weathering of materials and this also applies, to a lesser extent, to the light rare earth element fraction. In many studies of weathering profiles, "immobile" elements such as $\mathrm{Ti}, \mathrm{Zr}, \mathrm{Y}$ and $\mathrm{Nb}$, are used as internal references to evaluate the mobility of other elements (Nesbitt, 1979; Moore, 1998; Hill et al., 2000). The geochemical methods include also the determination of $\mathrm{Th} / \mathrm{U}$ values. In the current study, the $\mathrm{Th} / \mathrm{U}$ values ranged between 0.85 and $2.42 \mathrm{in}$ all profiles. The lowest value was seen in the genetic horizon Bw2 of the Xeric Haplocambid. In addition, the Ba/Nb ratio ranged from 32.88 to 105.13. There was irregular change in profiles with depth, and the highest weathering was in the Bk horizon of the Xeric Haplocalcid. There was a degree of substitution of $\mathrm{Sr}$ for $\mathrm{Ca}$ in $\mathrm{CaCO}_{3}$, and the variation in $(\mathrm{Rb}+\mathrm{Zr}) / \mathrm{Sr}$ was between 0.15 and 0.65 . There was a large variation of $\mathrm{CaCO}_{3}$ content in the profiles. $\mathrm{Ti}$ and $\mathrm{Zr}$ are often considered to be almost immobile; immobile index elements such as Ti and $\mathrm{Zr}$ are often used to identify enrichment or depletion of elements due to weathering and to calculate the mass balance relative mobility of other elements and soil discontinuities. They supplement the elemental concentration ratios of saprolite and parent bedrock to compensate for potential volume change during soil formation (Kabata-Pendias and Pendias, 1992; White, 1995). In the profiles studied, some weathering rates were quantified by using Zr. The values obtained when using $\mathrm{Zr}$ were homogenous, with $\mathrm{Zr} / \mathrm{Rb}$ ranging between 2.69 and 4.01 in each profile.

$\mathrm{X}$-ray diffractograms of selected samples are shown in Figure 3. According to these diffractograms, phyllosilicates of varying amounts and degrees of crystallization, including kaolinite at 1:1 and various minerals at 2:1, were formed in all four profiles. Peaks for most clay minerals were strong and indicated good crystallization. Mgsaturated clay exhibited three intensity peaks, at 1.44 to $1.40 \mathrm{~nm}, 0.95$ to $1.00 \mathrm{~nm}$, and 0.71 to $0.72 \mathrm{~nm}$. The 
reflection at $0.72 \mathrm{~nm}$ disappeared at $550^{\circ} \mathrm{C}$. The 1.4 to $1.5 \mathrm{~nm}$ peak was partially expanded from 1.6 to $1.5 \mathrm{~nm}$ by glycolation and it contracted to between 1.43 and $1.20 \mathrm{~nm}$ after $\mathrm{K}$ saturation at $20^{\circ} \mathrm{C}$. An ill-defined diffraction band was observed between 1.0 and $1.1 \mathrm{~nm}$ at $550^{\circ} \mathrm{C}$, indicating the presence of smectite (Sm), illite (I) and kaolinite (K). Illite was the most abundant clay mineral in profiles I, II and IV, whereas smectite was the most abundant clay mineral in profile III. XRD findings showed that the distribution of clay mineral types in surface horizons varied somewhat by profile, as follows: profile I, illite $>$ smectite $>$ kaolinite; profile II, illite $>$ smectite $>$ kaolinite; profile III, smectite > illite > kaolinite; and profile IV, illite > kaolinite > smectite.

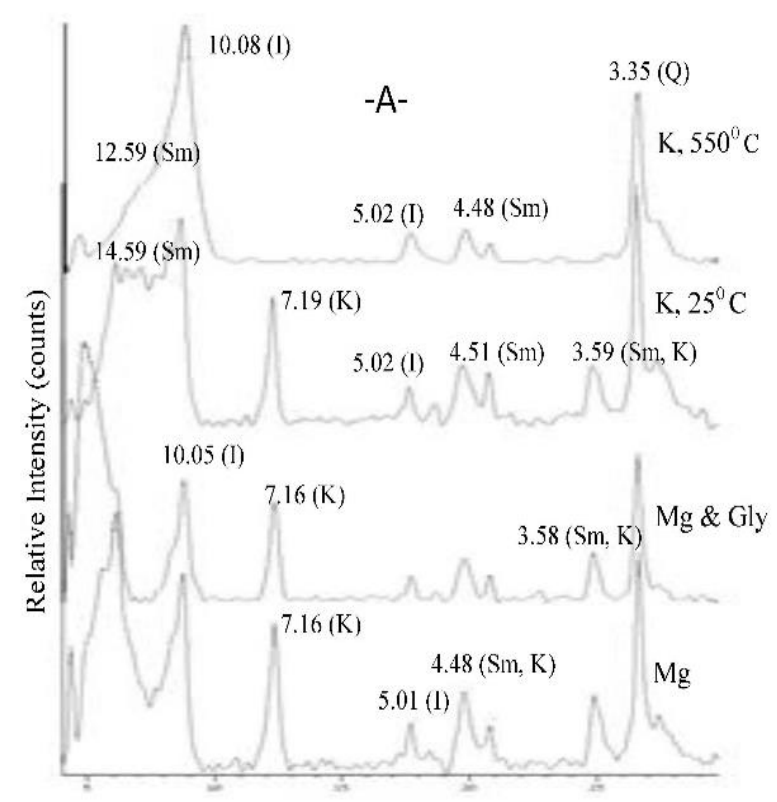

$2 \theta(\mathrm{deg})$

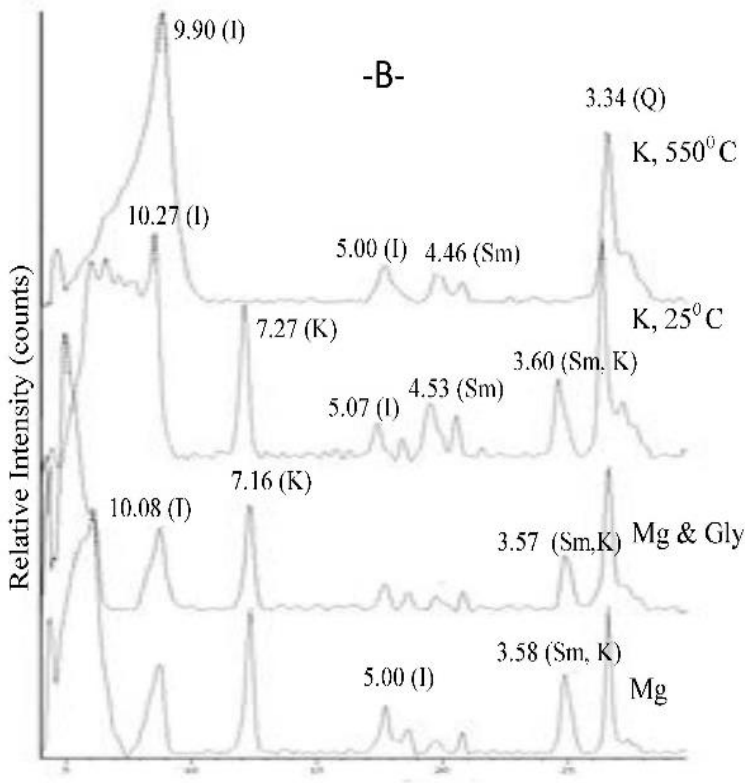

$2 \theta(\mathrm{deg})$
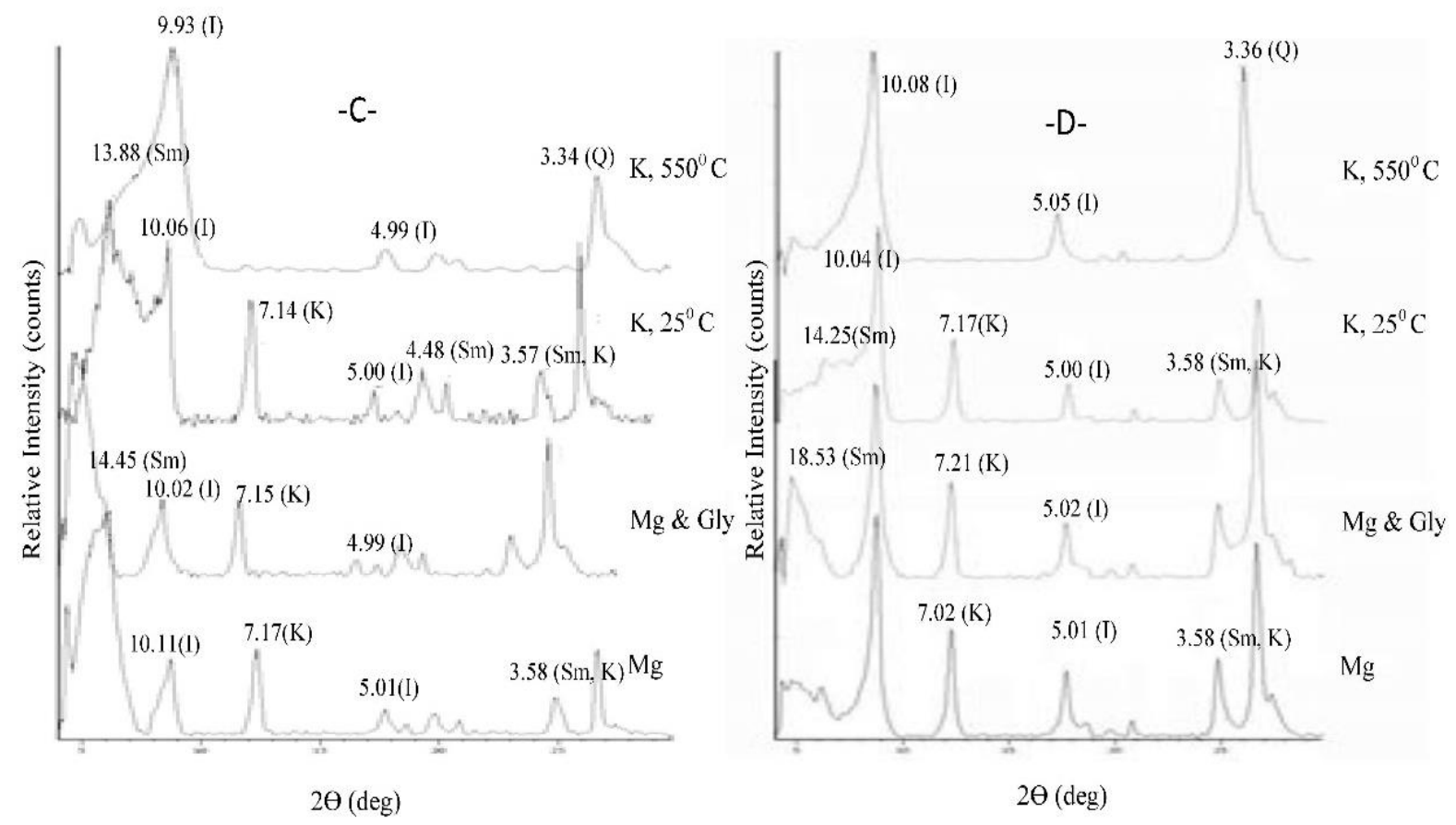

Figure 3. X-ray diffractograms of selected samples A: PI-Ap (0-21 cm), B: PII-Ap (0-21 cm), C: PIII- Ap (0-14 cm), D: PIV- Ap (0-24 cm), Smectite (Sm); Kaolinite (K); Illite (I), Quartz (Q). 


\section{Conclusion}

This study tested the hypothesis that, over time and using four soil profiles, climate had a greater effect than other soil-forming factors on the formation of aridisols developed on different parent materials experiencing but under similar semi-arid climate conditions, topographical position, land use and vegetation. Jenny (1946) stated that contrasting of mass and energy is useful when interpreting the relationship between parent material and climate. Important aspects of soil formation in regions with arid and semi-arid climates are the substantial diurnal changes in temperature which cause mechanical or physical disintegration of rock, and wind-blown sands that score and abrade exposed rock surfaces. The soil depth of these regions, in particular, governs the amount of soil moisture. Soil development in the Altınova State Farm at Konya in the Central Anatolia region of Turkey is a result of slow weathering, secondary calcium carbonate illuviation, structural development and a weathering ratio greater than 2 for silicon and aluminium. All profiles, except for profile IV, were generally of fine texture due to the parent material and the intensity of the weathering process. Weakly developed soils in the taxonomic classes Xeric Haplocambid and Xeric Haplocalcid were encountered in the study area. All profiles, except for profile III, had similar pedogenetic horizons as a consequence of soil formation processes (classification and development of structural B horizon), even though they have different parent materials, such as marl, limestone and old alluvial deposits. This situation can be explained by the modifications occurring as a result of the effects of environmental factors over time. There was no significant difference found between profiles I and II which were formed on the same parent material, except for the intensity of calcification symptoms (nodules, mycelium). In addition, it is widely recognized that the chemical composition of the parent material is responsible for the origin of some soil chemical properties such as the proportion of highly exchangeable basic cations and weathering ratio. Profile III formed on limestone and displayed differences in some morphological and mineralogical properties, such as having deep soil, a high clay content, and high smectite clay mineral content when compared with the other profiles. However, the parent material cannot be said to be a major factor in soil development. For most systems under local conditions, soil type is determined by a number of different criteria related to pedogenesis. In particular, the nature and intensity of the pedogenesis is largely controlled by combinations of other soil-forming factors, namely climate, land use, land cover and time.

This study clearly showed that climatic conditions strongly affect the soil physicochemical, mineralogical and morphological properties, either directly or indirectly, in the local area. These results were supported by the application of the chemical weathering indices, namely CIA, CIW, Base $/ \mathrm{R}_{2} \mathrm{O}_{3}\left(\mathrm{Al}_{2} \mathrm{O}_{3}+\mathrm{Fe}_{2} \mathrm{O}_{3}\right.$ sesquioxide or $\mathrm{R}_{2} \mathrm{O}_{3}$ ) and PIA, in this study. They are commonly used for characterizing weathering profiles by incorporating bulk major element oxide chemistry into a single metric for each sample.

In this study, we evaluated previously defined chemical weathering indices for their suitability for the characterization of weathering profiles developed on limestone-marl parent rocks and in different topographical positions. The fact that the physical, chemical and mineralogical characteristics of the profiles had limited variation, and that the weathering indices and anomalies determined with the use of geochemical characteristics show a very limited variation along profiles, indicate that the profiles show similar weathering levels, despite their different ages.

\section{Acknowledgement}

The authors thank TUBITAK in Ankara, Turkey for financial support for this project (TOVAG Project No: 1100729) and Gregory T. Sullivan of the University of Queensland in Brisbane, Australia for editing the English in an earlier version of this manuscript.

\section{References}

Alumaa, P., Steinnes, E., Kirso, U., Petersell, V., 2001. Heavy metal sorption by different Estonian soil types at low equilibrium solution concentration. Proceedings of the Estonian Academy of Sciences, Chemistry 50: 104-115

Ao, H., Deng, C., Dekkers, M.J., Sun, Y., Liu, Q., Zhu, R., 2010. Pleistocene environmental evoluation in the Nihewan Basin and implication for early human colonization of North China. Quaternary International 223-224: 472-478.

Birkeland, P.W., 1999. Soils and Geomorphology, Third edition. New York, Oxford University Press. 430 pp.

Black, C.A., 1965. Methods of Soil Analysis, Part II - Chemical and Microbiological Properties. Agronomy Monograph 9.1, American Society of Agronomy (ASA), Soil Science Society of America (SSSA), Madison, Wisconsin, USA.

Boul, S. W., Hole, F.D., McCracken, R.J., 1980. Soil Genesis Survey and Classification, Second edition. The Iowa University Press, Iowa.

Bouyoucos, G.J., 1951. Hydrometer method improved for making particle size analyses of soils. Agronomy Journal 54 (5): 419-434. 
Buringh, P., 1979. Introduction to the study of soils in tropical and subtropical regions. $3^{\text {rd }}$ edition. Centre for agricultural publishing and documentation: Wageningen, the Netherlands.

Chao, T.T., Sanzolone, R.F., 1992. Decomposition techniques. Journal of Geochemical Exploration 44 (1-3): 65-106.

Da Costa, P.Y.D., Nguetnkam, J.P., Mvoubou, C.M., Togbé, K.A., Ettien, J.B., Kouame, A.Y., 2015. Old landscapes, preweathered materials, and pedogenesis in tropical Africa: How can the time factor of soil formation be assessed in these regions?. Quaternary International 376: 47-74.

Darmody, R.G., Thorn, C.E., Allen, C.E., 2005. Chemical weathering and boulder mantles, Kärkevagge, Swedish Lapland. Geomorphology 67(1-2): 159-170.

de Meester, T., 1971. Highly Calcareous Lacustrine Soils in the Great Konya Basin, Turkey. Centre for Agricultural Publishing and Documentation, Wageningen, The Netherlands. 169p.

de Ridder, N.A., 1965. Sediments of the Konya Basin, Central Anatolia, Turkey. Palaeogeography, Palaeoclimatology, Palaeoecology 1: 225-227, 231-240, 243-254.

Dengiz, O. Sağlam, M., Özaytekin, H.H., Baskan, O., 2013. Weathering rates and some physico-chemical characteristics of soils developed on a calcic toposequences. Carpathian Journal of Earth and Environmental Sciences 8(2); 13-24.

Dengiz, 0., 2010. Morphology, physico-chemical properties and classification of soils on terraces of the tigris river in the South-East Anatolia Region of Turkey. Journal of Agricultural Sciences 16 (3): 205-212.

Dengiz, O., Göl, C., Karaca, S., Yüksel, M., 2006. Effects of different landsdcape position and parent material on soil variability and land use in both sides of Acicay river-Çankırı. In: Proceedings of the 5th International Soil Meeting (ISM) on Soil Sustaining Life on Earth, Managing Soil and Technology: May 22-26, Şanlıurfa, Turkey.

Dengiz, O., Usul, M., 2018. Multi-criteria approach with linear combination technique and analytical hierarchy process in land evaluation studies. Eurasian Journal of Soil Science 7(1): 20-29.

Dinc, U., Özbek, H., Kapur, A.S., Senol, S., 1987. Toprak Genesisi ve Sınıflandırılması, Cukurova University Press, Adana, Turkey, 379p. [In Turkish].

Driessen, P.M., 1970. Soil salinity and alkalinity in the Great Konya Basin, Turkey. Centre for Agricultural Publishing and Documentation, Wageningen, The Netherlands. 99p.

Driessen, P.M., de Meester, T., 1969. Soils of the Çumra Area, Turkey. Centre for Agricultural Publishing and Documentation, Wageningen, The Netherlands. 105p.

Duzgoren-Aydın, N.S., Aydın, A., Malpas, J., 2002. Re-assessment of chemical weathering indices: case study on pyroclastic rocks of Hong Kong. Engineering Geology 63(1-2): 99-119,

Fedo, C.M., Nesbitt, H.W., Young, G.M., 1995. Unraveling the effects of potassium metasomatism in sedimentary rocks and paleosols with implications for paleoweathering conditions and provenance. Geology 23(10): 921-924.

Gee, G.W., Bauder, J.W., 1986. Particle-size Analysis. In: Methods of Soil Analysis, Part 2, Chemical and Microbiological Properties, A.L. Page, R.H. Miller, D.R. Keeney (Eds.), 2nd Ed. Agronomy Monograph No. 9, ASA-SSSA, Madison, Wisconsin, USA. pp. 383-411.

Hamdan, J., Burnham, C.P., 1996. The contribution of nutrients from parent material in three deeply weathered soils of Peninsular Malaysia. Geoderma 74(3-4): 219-233.

Harnois, L., 1988. The CIW index: A new chemical index of weathering. Sedimentary Geology 55(3-4): 319-322.

Hill, I.G., Worden, R.H., Meighan, I.G., 2000. Yttrium: the immobility- mobility transition during basaltic weathering. Geology 28(10): 923-926.

Jenny, H., 1946. Arrangement of soil series and types according to functions of soil-forming factors. Soil Science 61(5): 375-391.

Johnson, D.L., Hole, F.D., 1994. soil formation theory: a summary of its principal impacts on geography, geomorphology, soil-geomorphology, quaternary geology and paleopedology, SSSA Special Publication 33. Factors of Soil Formation: A Fiftieth Anniversary Retrospective. pp,111-126.

Kabata-Pendias, A., Pendias, H., 1992. Trace elements in soil and plants. $2^{\text {nd }}$ Edition. CRC Press, Boca Raton, FL. 365p.

Kibar, M., Deniz, K., Sarıŏlu, F., 2012. The morphology, mineralogy, geochemistry and physical implications of foid bearing syenite and syenite-carbonate rocks contact zone soils: Kırşehir-Akpınar-Buzlukdağ, Turkey. Eurasian Journal of Soil Science 1(2); $69-74$.

Lark, R.M., 1999. Soil-landform relationships at within-field scales: an investigation using continuous classification. Geoderma 92(3-4): 141-165.

McLennan, S.M., 1993. Weathering and global denudation. Journal of Geology 101(2): 295- 303.

Moore, C.L., 1998. Evaluation of regolith development and element mobility during weathering using isocon technique. Geological Society of Australia Special Publication 20: 141-147.

Nesbitt, H.W., 1979. Mobility and fractionation of rare earth elements during weathering of a granodiorite. Nature 279: 206-210.

Nesbitt, Y.W., Young, G. M., 1982. Early Proterozoic climates and plate motions inferred from major element chemistry of lutites. Nature 299: 715-717.

Özaytekin, H.H., Karakaplan, S.M., 2012a. Soil formation on the Karadağ volcano at a semi arid environment from the Central Anatolia. African Journal of Agricultural Research 7(15): 2283-2296.

Özaytekin, H.H., Mutlu, H.H., Dedeoglu, M., 2012b. Soil formation on a calcic chronosequence of ancient Lake Konya in Central Anatolia, Turkey. Journal of African Earth Science 76: 66-74. 
Parker, A., 1970. An index of weathering for silicate rocks. Geological Magazine 107(6): 501-504.

Pope, G.A., Meierding, T.C., Paradise, T.R., 2002. Geomorphology's role in the study of weathering of cultural stone. Geomorphology 47(2-4): 211-225.

Price, J.R., Velbel, M.A., 2003. Chemical weathering indices applied to weathering profiles developed on heterogeneous felsic metamorphic parent rocks. Chemical Geology 202(3-4): 397-416,

Reiche, P., 1950. A survey of weathering processes and products, University of New Mexico Publications in Geology, 3, University of New Mexico Press. Albuquerque, 95p.

Roberts, N., Erol, O., de Meester, T., Uerpmann, H.P., 1979. Radiocarbon chronology of late Pleistocene Konya Lake, Turkey. Nature 281: 662-664.

Ruxton, B.P., 1968. Measures of the degree of chemical weathering of rocks. Journal of Geology 76(5): 518-527.

Schaetzl, R.J., Anderson, S., 2005. Soil Genesis and Geomorphology, Cambridge University Press, UK. 656p.

Shan, H.M., Liang, H.C., Peng, S.X., Longe, A.A., Zhou, A.G., 2010. Effects of water-saturation and water-loss processes on composition and structure variations of landslide, Three Gorges reservoir, China. In: Water- Rock Interaction. Birkle, P., Torres- Alvarado, I. S. (Eds.). CRC Press, New York, USA. pp. 921-924,

Soil Survey Laboratory, 2004. Soil Survey Laboratory Methods Manual. USDA Natural Resources Conservation Service. Soil Survey Investigations Report No 42. Washington D.C., USA.

Soil Survey Manual, 1993. Soil Survey Manual. USDA Agriculture Handbook No 18. Washington D.C., USA.

Soil Survey Staff., 1999. Soil taxonomy. A basic system of soil classification for making and interpreting soil survey. USDA Agriculture Handbook No 436. Washington D.C., USA.

Taylor, S.R., McLennan, S.M., 1985. The Continental Crust: its Composition and Evolution. Blackwell, Oxford, UK. 312p.

Vergouwen, L., 1981. Salt minerals and waters from soils in Konya and Kenya. PhD Thesis. Wageningen, The Netherland. 140p.

Vogt, T., 1927. Sulitjelmafeltets geologiog petrografi. Norges Geologiske Undersokelse 121: 1-560 [in Norwegian].

Walkley, A., Black, I.A., 1934. An examination of Degtjareff method for determining soil organic matter and a proposed modification of the chromic acid titration method. Soil Science 37(1):29-37.

White, A.F., 1995. Chemical weathering rates of silicate minerals in soils. In: Chemical weathering rates of silicate minerals, White, A.F., Brantley, S.L., (Eds.). Mineralogical Society of America Special Publication, 31, Mineralogical Society of America, Washington D.C.,USA. pp. 407-461.

Whittig, L.D., Allardice, W.R., 1986. X-ray diffraction techniques. In: Methods of Soil Analysis Part 1 Physical and Mineralogical Methods. 2nd Edition, Klute, A., (Ed). American Society of Agronomy, Soil Science Society of America. Madison, Wisconsin, USA. pp. 55-86.

Wood, D.A., Joron, J.L., Treuil, M., 1979. A re-appraisal of the use of trace elements to classify and discriminate between magma series erupted in different tectonic settings. Earth and Planetary Science Letters 45(2): 326-336.

Yang, S.Y., Jung, H.S., Li, C.X., 2004. Two unique weathering regimes in the Changjiang and Huanghe drainage basins: geochemical evidence from river sediments. Sedimentary Geology 164(1-2): 19-34. 